\section{7 㗋頭乳頭腫の微細構造}

$$
\begin{gathered}
\text { 。柴田浩一, 永井知幸, 伊藤正博, 鳥谷陽一 } \\
\text { 宗 } \text { (九 大) }
\end{gathered}
$$

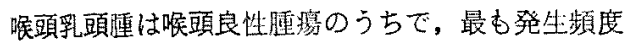
が高く、またその再発性・矔治性・侐性化に関して諭

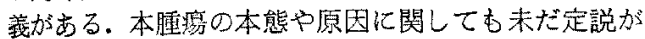
ない.小児呢頭乳頭腫洁多発性・易再発性・播種性よ りウイルス病因説が最も有力であり，てれに対して成 人型は臨床像も異なり悪性化する傾向がみられ，前癌 性変化という概念で考えられて来た。組織学的には小 児型之成人型には本質的差哄はみられないとする意見 か強く, 両者の関連古不明な点が多い。

わ机われは 2 例の再発性小坚啹頭乳頭腄老経験し， うち 1 例は 30 年後に悪性像を呈したので, 成人の呢 頭秏頭腫 1 例を加えて, その微細構造を梌索し, 本腫 溫の易再発性之悪性化化ついて考えたい。

症例 1 は 7 才男子， 2 才時上り喉頭に充満する乳頭

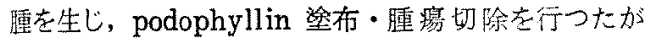
4 年間にわたり再発を繰返した。 6 才時に隀涴切除・ $5 \mathrm{FU}$ 噴簙を行い消失した。症例 2 は 34 才女子で 1 才時汇啹頭乳頭腫が生じ 10 数回にわたる切除・再発 を絽返し，4才時には Ra 照射 $340 \mathrm{mg} /$ 時を行つた。 以来経過良好であつたが 34 才時俘急激な呼吸困難を

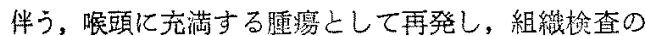
結果, 中等度分化型徧平上皮癌であつた。症例 3 は 50 才女子, 1 年前上り嗄声を来たし, 両側声帯前 $1 / 3$ に広基性乳頭状の腫㾤を認妉。組織検査の結果 papilloma であつた.

電顕試料は手術わよび生桧にて得られたものて，型 のごとく電顕標本を作製し観察した。

症例 1 は光影的には squamous cell papilloma で䉓頙像では基底膜はところどころ不連続で，久損部 より細胞質が㔖出していた。皮下の緒合組織の血管 は搪張していた。 基底細胞は变化に富み tonofilament, ribosome の集積した細胞質の豊富な細胞と 比較的明謂な細胞があり，核は chromatin に富み

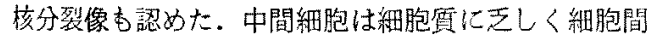
隙当应大し，多数の細胞突起を出し desmosome む 豊富で方つた。

昰例 2 の基底膜は不解明で凹凸著明で結合織との境 が不明暸であつた。細胞間陌は狭く細胞内橋は沫発達 て desmosome に乏しい, 胞体内に多数の riboso-

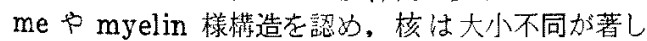
く, 明るく chromatin に之しい，核や紐胞内小器 官の崩壊像委多数認めた。

症例 3 は基底膜は逨続し，細胞質の突出はみら扎な い。上皮下には血管の搪張がみられた。基底糿胞は tonofilament, ribosomeに乏しし胞体は明るく， 核は chromatine に艺しく大きかつた。

\section{8 気道哷液繊毛系の走查電顕的 $\mathrm{X}$ 線微 量分析}

○山本真平, 三吉隶郎, 大山 勝, 非上ふさ
谷口 強, 山田清治

走查電顕にX線マイクロアナライザーを応用し, 気 道粘液維毛系の構成元素の分析を詿み，気道粘液䋐毛 系の機能之の関連性を追求した。

1）織毛域で，無織毛域に比してカルシウム元素 が多く存在した。しかむ，瀻毛細胞を制断し分析を行 う之, 絨毛部では, 胞体部に比してカルシウム元素が 硯位に存在した。このことはカルシウムイオンと瀻毛 運動乞密接な関倸があるという報告に照してはなはだ 毁味深い。

2）粘液層または分泌六進細胞ではイオウおよで元 素が多く存在した，肺炎桿菌ないしは HVJ ウイル スの経舅感染を行つたマウスにおいて，囍隆した無織 毛細胞捛よび粘液層を分析すると，コントロール群に 比して，イオウおよびリン元素が多く存在した，固定 時にルテニウムレット゚で処理すると，粘难層が綪毛先 端部に附着した状態て固定され，両者の相互関倸が明 膫に観察され，しかもこの部位の元素分析を行う之粘 液層にルテニウム元素のピークがみられた。 以上の成 績上り，気管粘䔶上皮の粘液層すな和方分泌物は，硫 酸基老有するムコ多糖体が主成分をなしているととが 窥える.

3）粘液繀毛系においては，時にケイ素を検出する 例が少なくない，元来，硫酸基を有する多糖体之蛋白 を絬合するのにケイ䋤をブリッジにして巨大な分子構 造をむつアミノグリカゴンが生体内化存在するととが 知ら机て扔り，このケイ素は単なるアーチフフクトと は断定できず，むしろ生体内に微量ではあるが存在し ながら粘液纎毛機能に重要な役彗を演しているととも 否定できない。

4）終末細気管枝のクララ細胞を分析すると，イオ ウ元奖以外に，特にリン元素の分布が著しい，現在 Surfactant の化学組成については、レシチンより成 るリン脂質とする説が支持されているが，今回その一 端をX線マイクロアナライザーによつて立祉すること ができた。

以上の成績を中心に，絬湤織毛系の梅成元菜上その 意義について落干の考察を加えて報告した。 